\title{
Knowledge, Attitude, and Practices of Food Handlers on Food Safety and Personal Hygiene During Arbaeenia Mass Gathering, Baghdad, Iraq, 2014: Cross-Sectional Study
}

Faris Lami ${ }^{1}$, MBChB, PhD, FFPH; Firas Radhi ${ }^{2}$, MBChB, DFE; Safauldeen Al Dahhan ${ }^{2}$, MBChB, DFE; Rana Adel Hashim $^{2}$, MBChB; Hussein Mahmood ${ }^{2}$, MBChB, DFE; Rawan Araj ${ }^{3}$, BSc, MPH; Ali Arbaji ${ }^{3}$, MD

${ }^{1}$ Department of Community and Family Medicine, College of Medicine, University of Baghdad, Baghdad, Iraq

${ }^{2}$ Iraq Ministry of Health, Baghdad, Iraq

${ }^{3}$ Global Health Development, Amman, Jordan

\section{Corresponding Author:}

Faris Lami, MBChB, PhD, FFPH

Department of Community and Family Medicine

College of Medicine

University of Baghdad

Bab Al Muadham, Rusafa

Baghdad, 00964

Iraq

Phone: 9647901402692

Email: farislami@gmail.com

\section{Abstract}

Background: Millions of pilgrims attend Arbaeenia mass gathering (MG) in Iraq each year. Thousands of individuals work voluntarily at temporary rest areas (locally called Mawakib), distributed in most of Iraq governorates, to provide food and other services to the MG attendees. The potential for improper handling of food at Mawakib increases the risk of waterborne and foodborne diseases.

Objective: This study was aimed to assess the knowledge, attitude, and practices (KAP) of food handlers in Mawakibs in Baghdad city during Arbaeenia MG.

Methods: A random sample of 100 Mawakibs was selected in Baghdad, 50 from the eastern side (Rusafa) and 50 from the western side (Kerkh), and five food handlers were randomly selected from each Mawakib. A questionnaire was used to collect demographic data and KAP for food safety and personal hygiene. The questionnaire included 25 questions addressing knowledge, 10 addressing attitudes, and 14 addressing practices of the food handlers with respect to food safety and personal hygiene. Questions on knowledge and attitudes were answered through direct interview with the food handlers, whereas the questions on practices were answered through direct observation while handling or serving the food. SPSS version 20 (IBM SPSS Statistics 20) was used for data analysis and describing proportions.

Results: There was a varied knowledge of food safety practices among the individuals interviewed. On a scale of 3 , the overall average score for both the attitude and practices for food safety and personal hygiene was 2, which corresponds to fair attitude and practices. The attitudes varied significantly by location, age group, and education, whereas the practices varied by location, age groups, employment, and previous experiences.

Conclusions: The food handlers had unsatisfactory attitudes and practices toward food handling and personal hygiene. Their participation in food handling at Mawakib carries a potential risk of spreading foodborne and waterborne diseases. All individuals intending to serve in Mawakib as food handlers should be licensed from the Ministry of Health after completing a formal training in food safety and personal hygiene.

(JMIR Public Health Surveill 2019;5(4):e10922) doi: 10.2196/10922

\section{KEYWORDS}

food; hygiene; knowledge; attitudes; Iraq 


\section{Introduction}

\section{Background}

Mass gatherings (MGs) are defined as the congregation of as few as 1000 individuals to upwards of 25,000 in a specific location for a designated period [1]. Such occurrences put a strain on the local resources, such as food, drinks, accommodation, and health care, and can pose a health risk to the population. Infectious diseases, such as foodborne and waterborne diseases, are considered a major public health concern during MGs, along with road traffic accidents, other injuries, and terrorism [2]. However, limited data are available on foodborne and waterborne disease outbreaks during MGs, largely because of poor health surveillance systems and limited research on population health during MGs.

Poor food safety and personal hygiene are the main risk factors for foodborne and waterborne illnesses; food handlers play an important role with regard to these risk factors [3]. Contaminated hands are vehicles for enteric virus transmissions, and food preparation and handling affect the safety of the food served [4]. In Iraq, religious MGs occur throughout the year, mainly in Karbala, Najaf, and Baghdad. Arbaeenia is the largest religious MG that annually convenes in Karbala, where more than 10 million people, mainly from Iraq, visit Imam Hussein's shrine in Karbala. Attendees walk hundreds of kilometers for many days to reach Karbala city.

Faith-based organizations and the general public are the main providers of water, food, shelter, accommodation, and, to a certain extent, health services in rest areas for pilgrims, locally called Mawakibs. Most of the individuals preparing and serving food are not certified food handlers, and Mawakibs are not regularly inspected by health authorities. The number of Mawakibs providing different services during the MGs has greatly increased over the last few years [5].

\section{Objectives}

The objective of this study was to assess the knowledge, attitude, and practices (KAP) of Mawakib food handlers with respect to food safety and personal hygiene during the Arbaeenia $\mathrm{MG}$ in Baghdad, Iraq, 2014.

\section{Methods}

\section{Study Design}

To assess the KAP of Mawakib food handlers with respect to food safety and hygiene, we conducted this cross-sectional study in Baghdad during the Arbaeenia MG, December 5 to December 9,2014. A simple random sample of 100 Mawakibs was selected from a list, which included the names and locations of these Mawakibs; 50 from Rusafa (eastern side of Baghdad) and 50 from Kerkh (western side of Baghdad). A total of 5 food handlers were selected from each Mawakib to participate in the study. Overall, 8 surveyors were trained to collect the data. The study was approved by the research committee of Iraq's Ministry of Health. The Mawakibs were selected after obtaining a list of all the Mawakibs and assigning them a sequential number to draw a random sample according to the calculated sample size.

\section{Questionnaire}

A questionnaire was used to collect data on the 3 domains of KAP. The questionnaire also collected data on sociodemographics and previous experience in food handling. Previous experience was defined as any former serving or food handling during similar events and MGs. The questionnaire was translated from English into Arabic (local dialect) and translated back to English to ensure accurate translation.

The questionnaire had 49 questions in total. Overall, 25 questions addressed the knowledge of food safety and personal hygiene. Furthermore, 10 questions addressed the attitudes toward food safety and personal hygiene habits while handling and serving food. A total of 14 questions addressed the practices of food handlers on food safety and hygiene when serving food to the visitors of the Mawakib during Arbaeenia MG. The knowledge and attitude sections of the questionnaire were completed through face-to-face interview, during which the data collectors verbally asked the questions to the study participants and then recorded their answers. The practices section of the questionnaire was completed by the data collectors based on their observations of the food handling practices.

The knowledge section of the questionnaire required yes or no responses. The practices and attitude sections required a response of always, sometimes, rarely, or never/refused. We assigned a score of 3 to always, a score of 2 to sometimes, a score of 1 to rarely, and 0 to never. However, refused and missing responses were excluded from the analysis.

\section{Data Analysis}

Data were coded and entered into Epi Info 7 (CDC's Epi Info 7) and SPSS version 20 (IBM Corp, Armonk, NY, USA) was used for data analysis. The percentage of food handlers who correctly answered the questions was calculated in the knowledge domain. For the questions on attitude and practices, the average scores were calculated for the responses to each question, in addition to the overall average score. The attitude and practices sections were categorized into poor, fair, and good, corresponding to the average scores of $<1.5,1.5$ to 2.4 , and 2.5 to 3 , respectively.

The percentage of respondents with poor, fair, or good attitudes and practices was estimated by sociodemographics. Chi-square tests and Fisher exact tests were used to test the association between KAP and sociodemographics. A $P$ value of less than .05 was considered statistically significant.

\section{Results}

\section{Food Handlers' Characteristics}

A total of 504 food handlers were interviewed. One data collector interviewed 6 instead of 5 food handlers in 4 Mawakibs. The food handlers were predominately male, in total $498(98.8 \%, 498 / 504)$. The average age of the food handlers was 37 (SD 12) years. Furthermore, 50.4\% (254/504) had secondary or postsecondary education. Only $3.2 \%(16 / 504)$ were basically full-time food handlers (Table 1). 
Table 1. Distribution of the food handlers during Arbaeenia mass gathering in Baghdad, Iraq, by sociodemographic characteristics and previous experience in food handling $(\mathrm{N}=504)$.

\begin{tabular}{|c|c|}
\hline Sociodemographic characteristics & Statistics, n (\%) \\
\hline \multicolumn{2}{|l|}{ Sex } \\
\hline Female & $6(1.2)$ \\
\hline Male & $498(98.8)$ \\
\hline \multicolumn{2}{|l|}{ Location } \\
\hline Karkh & $252(50.0)$ \\
\hline Rusafa & $252(50.0)$ \\
\hline \multicolumn{2}{|l|}{ Education level } \\
\hline Illiterate & $58(11.5)$ \\
\hline Presecondary & $192(38.1)$ \\
\hline Secondary & $161(31.9)$ \\
\hline Postsecondary & $93(18.5)$ \\
\hline \multicolumn{2}{|l|}{ Employment } \\
\hline Full-time food handler & $16(3.2)$ \\
\hline Unemployed or retired & $14(2.8)$ \\
\hline Full-time employee & $131(25.9)$ \\
\hline Student & $62(12.3)$ \\
\hline Day laborer & $281(55.8)$ \\
\hline \multicolumn{2}{|c|}{ Previous experience in food handling } \\
\hline No & $143(28.4)$ \\
\hline Yes & $361(71.6)$ \\
\hline
\end{tabular}

\section{Knowledge}

The percentage of food handlers who correctly answered questions related to food safety and personal hygiene ranged from $8 \%$ to $100 \%$. Poor knowledge was mainly related to storing food using ice baths, contaminating food with watches and rings that were worn, and food poisoning from eating perishables left out (Table 2).
Knowledge scores of the study participants were categorized into 3 categories: poor, fair, and good. The results of this score categorization and the statistical association with background variables are shown in Table 3. Knowledge of food handlers about food safety and personal hygiene was significantly associated with location $(P=.001)$ and job $(P=.04)$; full time employees had the best knowledge scores. 
Table 2. Responses to questions on knowledge by the study participants (N=504).

\begin{tabular}{|c|c|c|}
\hline Number & Knowledge items & Correct answer, $\mathrm{n}(\%)$ \\
\hline 1 & It is OK to mix raw meat with processed ones. & $41(8.1)$ \\
\hline 2 & Consumption of food in any container can be delayed. & $44(8.7)$ \\
\hline 3 & Ice baths—used as cooling systems—are not safe to store food for a prolonged time. & $167(33.5)$ \\
\hline 4 & Wearing rings and watch can contaminate food. & $396(78.6)$ \\
\hline 5 & Eating perishables left out for more than 2 hours at room temperature can lead to food poisoning. & $396(78.7)$ \\
\hline 6 & Multiple food tastings from the same dish can contaminate the dish with contagious microbes. & $403(80.3)$ \\
\hline 7 & Multiple people drinking from the same cup can contaminate the cup with contagious microbes. & $407(82.9)$ \\
\hline 8 & $\begin{array}{l}\text { Certain ways of handling food can cause food poisoning and encourage the growth of bacteria, viruses, and } \\
\text { parasites }\end{array}$ & $426(84.7)$ \\
\hline 9 & It is essential for food handlers to have a dry storage unit. & $422(85.3)$ \\
\hline 10 & Food handler with a cold can contribute to the spread of diseases while handling food. & $431(85.7)$ \\
\hline 11 & Infected wound can increase the risk of food poisoning while handling food. & $448(88.9)$ \\
\hline 12 & Food handler with a fever can contribute to the spread of diseases while handling food. & $452(89.7)$ \\
\hline 13 & Open sores can contribute to the spread of diseases while handling food. & $462(91.7)$ \\
\hline 14 & Vaccination is important to prevent the spread of diseases. & $466(93.3)$ \\
\hline 15 & Washing body frequently is important. & 469 (94.6) \\
\hline 16 & Smoking is a bad practice while handling food at Mawakibs. & $481(95.6)$ \\
\hline 17 & Food handlers should avoid preparing food if they are suffering from vomiting. & $487(96.6)$ \\
\hline 18 & Proper food covering can help prevent contamination. & $488(96.8)$ \\
\hline 19 & Food handlers should avoid preparing food if they are suffering from diarrhea. & $493(97.8)$ \\
\hline 20 & Food preparation must be done using clean equipment. & $493(97.8)$ \\
\hline 21 & Tidying hair and trimming finger nails contribute to your health positively. & $494(98.0)$ \\
\hline 22 & It is a good practice to use disposal utensils when serving food. & $495(98.2)$ \\
\hline 23 & The cooking equipment should be washed immediately after use. & $496(98.6)$ \\
\hline 24 & Washing hands should be a frequent practice. & $501(99.4)$ \\
\hline 25 & Food preparation must be done using potable water. & $503(99.8)$ \\
\hline
\end{tabular}


Table 3. Distribution of study participants by knowledge levels and background variables.

\begin{tabular}{|c|c|c|c|c|}
\hline \multirow[t]{2}{*}{ Background variables } & \multicolumn{4}{|c|}{ Knowledge levels } \\
\hline & Poor, n (\%) & Fair, n (\%) & Good, n (\%) & $P$ value \\
\hline Location & & & & .001 \\
\hline $\operatorname{Karkh}(\mathrm{N}=252)$ & $2(0.8)$ & $30(11.9)$ & $220(87.3)$ & \\
\hline Rusafa (N=252) & $24(9.5)$ & $117(46.4)$ & $111(44.0)$ & \\
\hline Age group (years) & & & & .22 \\
\hline$<20(\mathrm{~N}=30)$ & $3(10)$ & $13(43)$ & $14(47)$ & \\
\hline $20-39(\mathrm{~N}=275)$ & $15(5.5)$ & $71(25.8)$ & $189(68.7)$ & \\
\hline $40-59(\mathrm{~N}=181)$ & $7(3.9)$ & $56(30.9)$ & $118(65.2)$ & \\
\hline$\geq 60(\mathrm{~N}=18)$ & $1(6)$ & $7(39)$ & $10(56)$ & \\
\hline Education level & & & & .57 \\
\hline Illiterate $(\mathrm{N}=58)$ & $2(3)$ & $21(36)$ & $35(60)$ & \\
\hline Subsecondary $(\mathrm{N}=192)$ & $13(6.8)$ & $55(28.6)$ & $124(64.6)$ & \\
\hline Secondary $(\mathrm{N}=161)$ & $9(5.6)$ & $43(26.7)$ & $109(67.7)$ & \\
\hline Higher education $(\mathrm{N}=93)$ & $11(12)$ & $16(17)$ & $76(82)$ & \\
\hline Job & & & & .04 \\
\hline Full-time food handler $(\mathrm{N}=16)$ & $1(6)$ & $8(50)$ & $7(44)$ & \\
\hline Unemployed/retired (N=14) & $0(0)$ & $4(29)$ & $10(71)$ & \\
\hline Full-time employee $(\mathrm{N}=131)$ & $3(2.3)$ & $18(13.7)$ & $110(83.9)$ & \\
\hline Student $(\mathrm{N}=62)$ & $4(6)$ & $16(26)$ & $42(68)$ & \\
\hline Day laborer $(\mathrm{N}=281)$ & $8(2.8)$ & $52(18.5)$ & $221(78.6)$ & \\
\hline Previous experience & & & & .09 \\
\hline No $(\mathrm{N}=143)$ & $7(4.9)$ & $32(22.4)$ & $104(72.7)$ & \\
\hline Yes $(\mathrm{N}=361)$ & $19(5.3)$ & $115(31.9)$ & $227(62.9)$ & \\
\hline
\end{tabular}

\section{Attitude}

On a 3-point scale, the overall average score of the questions on attitude was 2. A total of 6 questions had an average score of 2 , and 4 questions had 3. The distribution of responses to attitude questions is shown in Table 4.

The overall attitude of food handlers toward food safety and personal hygiene while handling and serving food was scored as fair.
Attitude scores of the study participants were categorized into 3 categories: poor, fair, and good. The results of this score categorization and the statistical association with background variables are shown in Table 5. Attitude scores were significantly associated with location (better in Kerkh; $P=.001$ ), age $(P=.01)$, education $(P=.008)$, and previous experience with food handling $(P=.03)$. 
Table 4. Distribution of responses to questions on attitude.

\begin{tabular}{|c|c|c|c|c|}
\hline Number & Attitude items & Always, n (\%) & Sometimes, n (\%) & Rarely, n (\%) \\
\hline 1 & $\begin{array}{l}\text { Staying home instead of going to Mawakib to serve food when } \\
\text { having vomiting }\end{array}$ & $373(74.0)$ & $81(16.1)$ & $50(9.9)$ \\
\hline 2 & $\begin{array}{l}\text { Staying home instead of going to Mawakib to serve food when } \\
\text { having diarrhea }\end{array}$ & $373(74.0)$ & $81(16.1)$ & $50(9.9)$ \\
\hline 3 & $\begin{array}{l}\text { Staying home instead of going to Mawakib to serve food when } \\
\text { having open sores }\end{array}$ & $383(76.0)$ & $66(13.1)$ & $55(10.9)$ \\
\hline 4 & Not wearing rings and watch during food handling & $373(74.0)$ & $96(19.1)$ & $35(6.9)$ \\
\hline 5 & $\begin{array}{l}\text { Staying home instead of going to Mawakib to serve food when } \\
\text { having an infected wound }\end{array}$ & $393(78.0)$ & $61(12.1)$ & $50(9.9)$ \\
\hline 6 & $\begin{array}{l}\text { Staying home instead of going to Mawakib to serve food when } \\
\text { having a cold }\end{array}$ & $403(80.0)$ & $61(12.1)$ & $40(7.9)$ \\
\hline 7 & Encourage food handlers to get vaccinated & $428(84.9)$ & $45(8.9)$ & $31(6.2)$ \\
\hline 8 & Tidying hair and trimming finger nails & $423(83.9)$ & $76(15.1)$ & $5(1.0)$ \\
\hline 9 & Washing body & $443(87.9)$ & $55(10.9)$ & $6(1.2)$ \\
\hline 10 & Washing hands as necessary & $454(90.1)$ & $45(8.9)$ & $5(1.0)$ \\
\hline
\end{tabular}

Table 5. Distribution of the study participants by attitude levels and background variables.

\begin{tabular}{|c|c|c|c|c|}
\hline \multirow[t]{2}{*}{ Background variable } & \multicolumn{3}{|c|}{ Attitude levels } & \multirow[t]{2}{*}{$P$ value } \\
\hline & Poor, n (\%) & Fair, n (\%) & Good, n (\%) & \\
\hline Location & & & & .001 \\
\hline Kerkh $(\mathrm{N}=252)$ & $66(26.2)$ & $100(39.7)$ & $86(34.1)$ & \\
\hline Rusafa (N=252) & $112(44.4)$ & $103(40.9)$ & $37(14.7)$ & \\
\hline Age group (years) & & & & .01 \\
\hline$<20(\mathrm{~N}=30)$ & $13(43)$ & $10(33)$ & $7(23)$ & \\
\hline $20-39(\mathrm{~N}=275)$ & $77(28.0)$ & $122(44.4)$ & $76(27.6)$ & \\
\hline $40-59(\mathrm{~N}=181)$ & $82(45.3)$ & $64(35.4)$ & $35(19.3)$ & \\
\hline$\geq 60(\mathrm{~N}=18)$ & $6(33)$ & $7(39)$ & $5(28)$ & \\
\hline Education level & & & & .008 \\
\hline Illiterate $(\mathrm{N}=58)$ & $15(26)$ & $19(33)$ & $24(41)$ & \\
\hline Subsecondary $(\mathrm{N}=192)$ & $77(40.1)$ & $83(43.2)$ & $32(16.7)$ & \\
\hline Secondary $(N=161)$ & $58(36.0)$ & $60(37.3)$ & $43(26.7)$ & \\
\hline Higher education $(\mathrm{N}=93)$ & $28(30)$ & $41(44)$ & $24(26)$ & \\
\hline Job & & & & .11 \\
\hline Full-time food handler $(\mathrm{N}=16)$ & $2(13)$ & $11(69)$ & $3(19)$ & \\
\hline Unemployed or retired $(\mathrm{N}=14)$ & $8(57)$ & $6(43)$ & $0(0)$ & \\
\hline Full-time employed (N=131) & $45(34.4)$ & $53(40.5)$ & $33(25.2)$ & \\
\hline Student $(\mathrm{N}=62)$ & $24(39)$ & $26(42)$ & $12(19)$ & \\
\hline Day laborer $(\mathrm{N}=281)$ & $99(35.2)$ & $107(38.1)$ & $75(26.7)$ & \\
\hline Previous experience & & & & .03 \\
\hline No $(\mathrm{N}=143)$ & $59(41.3)$ & $60(41.9)$ & $24(16.8)$ & \\
\hline Yes $(\mathrm{N}=361)$ & $119(32.9)$ & $143(39.6)$ & $99(27.4)$ & \\
\hline
\end{tabular}




\section{Practices}

The overall average score for responses on practices for food safety and personal hygiene was 2 ; the average score of 7 of the questions was 2 and the remaining 7 averaged a score of 3 (Table 6). The overall practice of food handlers was therefore fair.
Practice scores of the study participants were categorized into 3 categories: poor, fair, and good. The results of this score categorization and the statistical association with background variables are shown in Table 7. The practice scores were significantly associated with the location (better in Kerkh; $P=.001)$ and previous experience with food handling $(P=.001)$.

Table 6. The distribution of responses to questions on practices.

\begin{tabular}{|c|c|c|c|c|c|}
\hline Number & Practice items & Always, n (\%) & Sometimes, n (\%) & Rarely, n (\%) & No response, $\mathrm{n}(\%)$ \\
\hline 1 & $\begin{array}{l}\text { Not serving food for visitors, which has } \\
\text { been kept in containers for a long time }\end{array}$ & $359(71.2)$ & $55(10.9)$ & $30(6.0)$ & $60(11.9)$ \\
\hline 2 & $\begin{array}{l}\text { Not using ice baths as a cooling system to } \\
\text { store food for a prolonged time }\end{array}$ & $277(55.0)$ & $76(15.0)$ & $10(2.0)$ & $141(28.0)$ \\
\hline 3 & Using dry storage unit to store food & $418(83.0)$ & $40(7.9)$ & $15(3.0)$ & $81(16.1)$ \\
\hline 4 & $\begin{array}{l}\text { Not allowing multiple visitors to taste food } \\
\text { from the same dish }\end{array}$ & $328(65.0)$ & $35(6.9)$ & $10(2.0)$ & $131(26.0)$ \\
\hline 5 & $\begin{array}{l}\text { Not allowing multiple visitors to drink } \\
\text { from the same cup }\end{array}$ & $328(65.0)$ & $30(6.0)$ & $10(2.0)$ & $136(27.0)$ \\
\hline 6 & $\begin{array}{l}\text { Not smoking while handling food at } \\
\text { Mawakib }\end{array}$ & $333(66.0)$ & $35(7)$ & $5(1)$ & $131(26)$ \\
\hline 7 & $\begin{array}{l}\text { Not reheating the food more than once } \\
\text { before serving it }\end{array}$ & $337(67.0)$ & $30(6.9)$ & $45(8.9)$ & $91(18.1)$ \\
\hline 8 & $\begin{array}{l}\text { Using disposal units to serve food for vis- } \\
\text { itors }\end{array}$ & $343(68.0)$ & $25(5.0)$ & $5(1.0)$ & $131(26.0)$ \\
\hline 9 & $\begin{array}{l}\text { Not serving perishables left out for more } \\
\text { than } 2 \text { hours at room temperature for visi- } \\
\text { tors }\end{array}$ & $338(67.0)$ & $35(6.9)$ & $5(1.0)$ & $126(25.0)$ \\
\hline 10 & $\begin{array}{l}\text { Washing cooking equipment immediately } \\
\text { after use }\end{array}$ & $358(71.0)$ & $10(2.0)$ & $5(1.0)$ & $131(26.0)$ \\
\hline 11 & $\begin{array}{l}\text { Covering food properly to prevent contam- } \\
\text { ination }\end{array}$ & $358(71.0)$ & $10(2.0)$ & $5(1.0)$ & $131(26.0)$ \\
\hline 12 & Preparing food using potable water & $358(71)$ & $15(3.0)$ & $2(0.4)$ & $129(25.6)$ \\
\hline 13 & Separating raw meat from processed ones & $363(72.0)$ & $10(2.0)$ & $5(1.0)$ & $126(25.0)$ \\
\hline 14 & Preparing food using clean equipment & $368(73.0)$ & $9(1.8)$ & $1(0.2)$ & $126(25.0)$ \\
\hline
\end{tabular}


Table 7. Distribution of the study participants by practice levels and background variables.

\begin{tabular}{|c|c|c|c|c|}
\hline \multirow[t]{2}{*}{ Background variables } & \multicolumn{4}{|c|}{ Practice levels } \\
\hline & Poor, n (\%) & Fair, n (\%) & Good, n (\%) & $P$ value \\
\hline Location & & & & .001 \\
\hline Kerkh $(\mathrm{N}=252)$ & $58(23.0)$ & $70(27.8)$ & $124(49.2)$ & \\
\hline Rusafa (N=252) & $119(47.2)$ & $90(35.7)$ & $43(17.1)$ & \\
\hline Age group (years) & & & & .08 \\
\hline$<20(\mathrm{~N}=30)$ & $13(43)$ & $8(27)$ & $9(30)$ & \\
\hline $20-39(\mathrm{~N}=275)$ & $83(30.2)$ & $88(32.0)$ & $104(37.8)$ & \\
\hline $40-59(\mathrm{~N}=181)$ & $75(41.4)$ & $60(33.1)$ & $46(25.4)$ & \\
\hline$\geq 60(\mathrm{~N}=18)$ & $6(33)$ & $4(22)$ & $8(44)$ & \\
\hline Education level & & & & .05 \\
\hline Illiterate $(\mathrm{N}=58)$ & $16(28)$ & $20(34)$ & $22(38)$ & \\
\hline Subsecondary $(\mathrm{N}=192)$ & $54(28.1)$ & $70(36.5)$ & $68(35.4)$ & \\
\hline Secondary $(\mathrm{N}=161)$ & $65(40.4)$ & $47(29.2)$ & $49(30.4)$ & \\
\hline Higher education $(\mathrm{N}=93)$ & $42(45)$ & $23(25)$ & $28(30)$ & \\
\hline Job & & & & .06 \\
\hline Full-time food handler $(\mathrm{N}=16)$ & $3(19)$ & $8(50)$ & $5(31)$ & \\
\hline Unemployed or retired $(\mathrm{N}=14)$ & $6(43)$ & $6(43)$ & $2(14)$ & \\
\hline Full-time employed $(\mathrm{N}=131)$ & $38(29.0)$ & $40(30.5)$ & $53(40.5)$ & \\
\hline Student $(\mathrm{N}=62)$ & $31(50)$ & $15(24)$ & $16(26)$ & \\
\hline Day laborer $(\mathrm{N}=281)$ & $99(35.2)$ & $91(32.4)$ & $91(32.4)$ & \\
\hline Previous experience & & & & .001 \\
\hline No $(N=143)$ & $33(23.1)$ & $43(30.1)$ & $67(46.9)$ & \\
\hline Yes $(\mathrm{N}=361)$ & $134(39.9)$ & $117(32.4)$ & $100(27.7)$ & \\
\hline
\end{tabular}

\section{Discussion}

\section{Principal Findings}

The study shows that the food handlers serving Arbaeenia MG attendees had satisfactory knowledge, fair attitudes, and fair practices with respect to food safety and personal hygiene. According to sociodemographics, the attitudes and practices of the food handlers varied.

Correct knowledge regarding food safety and personal hygiene varied among the food handlers. A lack of knowledge on food safety measures, such as proper preparation and storage, carries the risk for potential events of foodborne diseases. Similar findings of lack of knowledge were present in previously conducted KAP studies of food handlers [6,7]. Mawakib food handlers are volunteers and not all the handlers reported prior experience in food handling, which may explain a lack of knowledge in food safety and personal hygiene. Variation in knowledge may be because of the lack of training and information, as reported in similar studies [8,9].

The findings on the attitudes of the food handlers toward food safety and personal hygiene habits were similar to the findings on the practices. Attitudes have an impact on practices, as observed in other KAP studies [10]. Attitudes and practices varied significantly according to location and age, which suggests that attitudes may have shaped the observed practices of the food handlers. The results of this study indicated that the lowest education level (illiterate) had a higher percentage of food handlers with good attitudes toward food safety and personal hygiene than all other education levels. In the domain of practices, food handlers with secondary education had the highest percentage of good practices. These findings suggest that there is no strong correlation between the education level and the attitudes and practices of food handlers; similar findings in previous studies suggest that education level does not influence food safety and personal hygiene [11].

\section{Conclusions}

We can conclude that in spite of satisfactory knowledge, the current attitudes and practices of food handlers are not satisfactory; a finding that makes their participation in provision of food for MG attendees in Mawakib a noticeable risk. Iraq's Ministry of Health is requested to make rigorous standards and licensure mandatory for all individuals intending to serve in Mawakib as food handlers. They have to complete a formal training in food safety and personal hygiene.

The results of this study cannot be generalized on all Mawakibs throughout the country as the study was conducted in only 1 city. Hence, one of the recommendations to the Ministry of 
Health is to conduct a large-scale survey in all cities affected with the MGs and serving of food to have clear guidance on

food safety and the needed regulations.

\section{Acknowledgments}

The authors acknowledge the financial support from the Eastern Mediterranean Public Health Network to conduct this study.

\section{Conflicts of Interest}

None declared.

\section{References}

1. World Health Organization. 2009. Interim Planning Considerations for Mass Gatherings in the Context of Pandemic (H1N1) 2009 Influenza URL: https://www.who.int/csr/resources/publications/swineflu/h1n1_mass_gatherings/en/ [accessed 2019-09-03]

2. The WHO Regional Office for the Eastern Mediterranean. 2012. International Health Regulations (IHR): Health Preparedness at Mass Gatherings, October 2012, Iraq and Jordan URL: http://www.emro.who.int/international-health-regulations/ ihr-events/health-preparedness-at-mass-gatherings.html [accessed 2019-08-30]

3. Aziz SA, Dahan HM. Food handlers' attitude towards safe food handling in school canteens. Procedia Soc Behav Sci 2013 Dec;105:220-228. [doi: 10.1016/j.sbspro.2013.11.023]

4. Lillquist DR, McCabe ML, Church KH. A comparison of traditional handwashing training with active handwashing training in the food handler industry. J Environ Health 2005;67(6):13-6, 28. [Medline: 15690900]

5. Global Sponsor Network. 2013. [Number of Processions and Husseini Organizations Participating in the Forty Season] URL: http://alkafeel.net/ar-news/index.php?id=1486 [accessed 2019-08-30]

6. Martins RB, Hogg T, Otero JG. Food handlers' knowledge on food hygiene: the case of a catering company in Portugal. Food Control 2012 Jan;23(1):184-190. [doi: 10.1016/j.foodcont.2011.07.008]

7. Chukwuocha UM, Dozie IN, Amadi AN, Nwankwo BO, Ukaga CN, Aguwa OC, et al. The knowledge, attitude and practices of food handlers in food sanitation in a metropolis in south eastern Nigeria. East Afr J Public Health 2009 Dec;6(3):240-243. [Medline: 20803912]

8. Liu S, Liu Z, Zhang H, Lu L, Liang J, Huang Q. Knowledge, attitude and practices of food safety amongst food handlers in the coastal resort of Guangdong, China. Food Control 2015 Jan;47:457-461. [doi: 10.1016/j.foodcont.2014.07.048]

9. Kibret M, Abera B. The sanitary conditions of food service establishments and food safety knowledge and practices of food handlers in Bahir Dar town. Ethiop J Health Sci 2012 Mar;22(1):27-35 [FREE Full text] [Medline: 22984329]

10. Abdul-Mutalib N, Abdul-Rashid M, Mustafa S, Amin-Nordin S, Hamat RA, Osman M. Knowledge, attitude and practices regarding food hygiene and sanitation of food handlers in Kuala Pilah, Malaysia. Food Control 2012 Oct;27(2):289-293. [doi: 10.1016/j.foodcont.2012.04.001]

11. Isara A, Isah E. Knowledge and practice of food hygiene and safety among food handlers in fast food restaurants in Benin city, Edo state. Niger Postgrad Med J 2009 Sep;16(3):207-212. [doi: 10.1016/j.puhe.2010.03.028] [Medline: 19767908]

\section{Abbreviations \\ KAP: knowledge, attitude, and practices \\ MG: mass gathering}

Edited by Y Khader, M Smolinski; submitted 30.04.18; peer-reviewed by P Okojie, G Sharkas; comments to author 07.12.18; revised
version received 02.04.19; accepted 03.04.19; published 09.10.19
Please cite as:
Lami F, Radhi F, Al Dahhan S, Hashim RA, Mahmood H, Araj R, Arbaji A
Knowledge, Attitude, and Practices of Food Handlers on Food Safety and Personal Hygiene During Arbaeenia Mass Gathering,
Baghdad, Iraq, 2014: Cross-Sectional Study
JMIR Public Health Surveill 2019;5(4):e10922
URL: $\underline{\text { https://publichealth.jmir.org/2019/4/e10922 }}$
doi: $\underline{10.2196 / 10922}$
PMID: $\underline{31599735}$

(CFaris Hasan Lami, Firas Radhi, Safauldeen Al Dahhan, Rana Adel Hashim, Hussein Mahmood, Rawan Araj, Ali Arbaji. Originally published in JMIR Public Health and Surveillance (http://publichealth.jmir.org), 09.10.2019. This is an open-access 
article distributed under the terms of the Creative Commons Attribution License (https://creativecommons.org/licenses/by/4.0/), which permits unrestricted use, distribution, and reproduction in any medium, provided the original work, first published in JMIR Public Health and Surveillance, is properly cited. The complete bibliographic information, a link to the original publication on http://publichealth.jmir.org, as well as this copyright and license information must be included. 